\title{
二種の混合ガスの混合率および流量測定システムの 精度向上に関する研究
}

\author{
尹 鍾 晧*・向 後 晃**・川嶋 健 嗣*・香川 利 春* \\ Accuracy Improvement of a Concentration and Flow \\ Measurement System for Binary Gas Mixtures \\ Chongho Youn*, Akira Kogo**, Kenji Kawashima* and Toshiharu Kagawa*

\begin{abstract}
This study intends to improve the accuracy of the concentration and flow measurement system for binary gas mixtures that was developed by two of the present authors ${ }^{11}$. This system is composed of a venturi tube and a laminar flowmeter connected in series. A basic examination on the viscosity estimate for binary gas mixtures and a preliminary measurement of the flow coefficient of the venturi tube are carried out. The procedure of concentration calculation based on the basic study is also shown. The estimate accuracy of the mole fractions of component gases and the flow rate of binary gas mixtures are experimentally examined using three kinds of mixed gas : $\mathrm{CO}_{2}{ }^{-}$ Air, $\mathrm{CO}_{2}-\mathrm{Ar}$ and $\mathrm{Ar}-\mathrm{He}$. The results indicate that the mole fractions can be estimated with accuracy of $5 \%$ and the flow rate can be estimated with accuracy of $2 \%$.
\end{abstract}

Key Words : gas mixture, gas concentration measurement, laminar flowmeter, venturi flowmeter

\section{1. はじめに}

屋外を含む作業現場において，異種ガスの混合比の迅速な 測定が求められることがある。たとえば，ガス配管の保守点 検作業においては，配管内にある可燃性ガスを安全な窒素に 置換するパージ作業を行なうが2)，配管内のガスを無駄なく 置換することにより，パージに使用される窒素ガスの量を減 らすことができる。この種の作業を手早く，かつ無駄なく行 なうためには，配管内における流量と混合比率計測を同時か つリアルタイムに測定する必要がある.

ガスの混合比率測定には，ガスクロマイクロトロフィー 法 $^{3)}$, 赤外線吸光光度法 ${ }^{4}$, 光干渉計式, 熱伝導法, 半導体 法，超音波法5) などがある。これらの方法は当然であるが, 測定精度やガスの種類の範囲が広いことなどに努力が払われ ており，測定系の応答速度に関心を払ったものではない。そ れゆ元，応答は数十秒程度と遅く，混合比が短時間で大きく 変わる現場への適用は難しい.

* 東京工業大学精密工学研究所 横浜市長津田町 4259

**ソニー株式会社厚木第 2 テクノロジーセンター 厚木市岡田 4-16-1

* Precision and Intelligence Laboratory, Tokyo Institute of Technology, 4259 Nagatsuta-cho, Yokohama

** Sony Corporation, Atsugi Technology Center 2, 4-16-1 Okada, Atsugi

(Received September 29, 2010)

(Revised July 13, 2011)
そこで，実質的にリアルタイムで測定を行なうことができ るベンチュリ管流量計と層流型流量計6) を用いて，二種のガ スのモル分率と流量を同時かつ高速に求める計測システムが 著者らによって提案された ${ }^{1)}$.この測定システムが，ガスの 混合比率を従来機器より 10 倍以上早い 0.2 秒で測定できる ことを，アルゴンー空気と二酸化炭素一空気を用いた混合ガ スを用いて，実験的検証を行なった。

しかし，測定精度が $\pm 10 \%$ 程度にとどまり，測定精度を向 上することが課題であった。本研究ではこの課題を扱う.

2 章では, すでに提案したシステム ${ }^{11}$ の構造を中心に必要 事項を説明する。 3 章では, 前報まで1,2) では, 定数とみな していたベンチュリ管の膨張係数および流出係数の検討と, 粘度算定式の誤差補正を考察し，混合率が既知の場合に，流 量および粘度が精度よく求められるようにする. 4 章は 2 つ の流量計に生じる差圧から, 流量と混合比を算定する問題を 扱う。これは本論文の主題部分である. 5 章で結論を述べ る。

\section{主な記号}

$d_{L}$ 層流型流量計細管直径 [m]

$d_{V}$ ベンチュリ管スロート直径 $[\mathrm{m}]$

$D_{V}$ ベンチュリ管入り口直径 $[\mathrm{m}]$

$G$ 質量流量 $[\mathrm{kg} / \mathrm{s}]$

$k_{V}$ ベンチュリ管流量計の係数 $\left[\mathrm{m}^{2}\right]$

$K_{L} \quad$ 層流型流量計の係数 $\left[\mathrm{m}^{3}\right]$ 


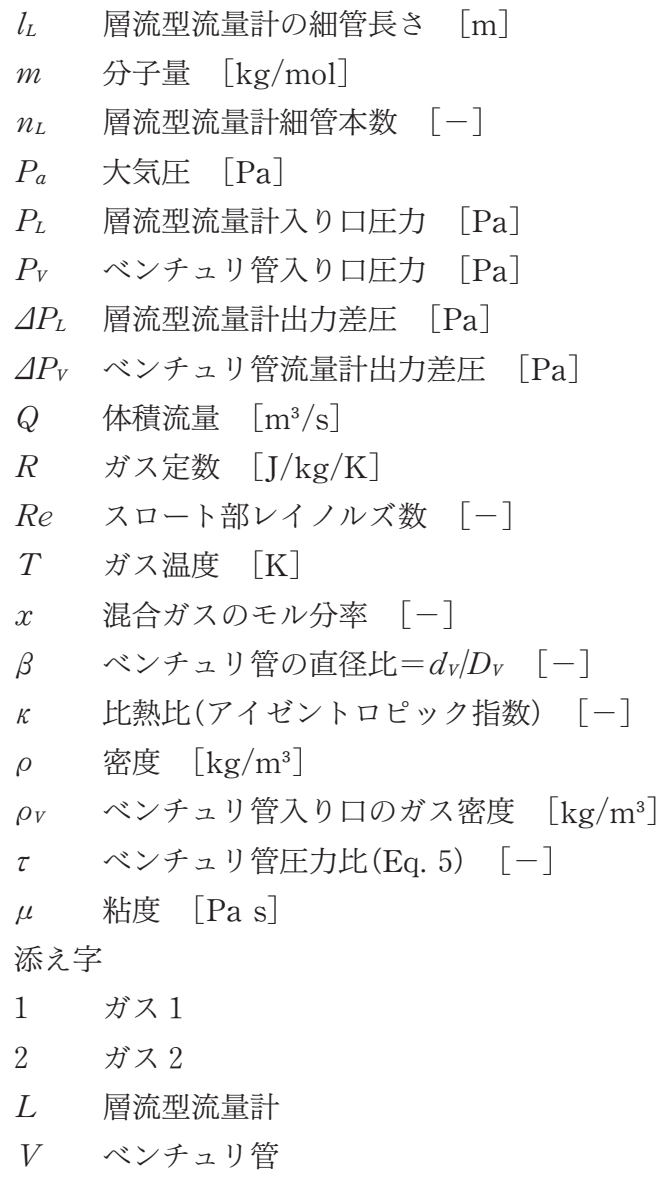

\section{2. 測 定 原 理}

測定システムの概略図を Fig. 1 に示す。混合ガス成分の モル分率と流量を同時に知るために，測定原理の異なる $2 つ$ の流量計，ここでは，ベンチュリ管と層流型流量計を用い た.

このシステムでは, 精度向上が目的であるから, 厳密を期 すために，質量流量が両流量計で等しいという，物理的関係 をもとに計算式を考察する。ベンチュリ管における，流量と 差圧の関係は以下の式で与えられる7).

$$
Q_{V}=k_{V} \sqrt{\frac{2 \Delta P_{V}}{\rho_{V}}}
$$

ただし

$$
k_{V}=\frac{C}{\sqrt{1-\beta^{4}}} \varepsilon \frac{\pi}{4} d_{V}^{2}
$$

$C$ は流出係数, $\varepsilon$ はガスの膨張補正係数である.ここで与 えられる流量の評価は体積流量であるから, 質量流量は,

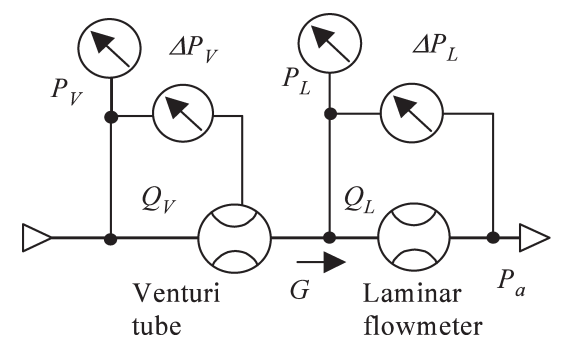

Fig. 1 Mixed gas measurement system

$$
G=G_{V}=\rho_{V} Q_{V}
$$

である. 膨張補正係数 $\varepsilon$ は以下の式で与えられる7) 9).

$$
\varepsilon=\sqrt{\left(\frac{\kappa \tau^{2 / \kappa}}{\kappa-1}\right)\left(\frac{1-\beta^{4}}{1-\beta^{4} \tau^{2 / \kappa}}\right)\left(\frac{1-\tau^{(\kappa-1) / \kappa}}{1-\tau}\right)}
$$

ただし

$$
\tau=\left(P_{V}-\Delta P_{V}\right) / P_{V}
$$

つぎに，層流型流量計における質量流量は，つぎのとおり である.

$$
G=G_{L}=n_{L} \frac{\pi d_{L}^{4}\left(P_{L}^{2}-P_{a}^{2}\right)}{256 \mu l_{L} R T}
$$

さて, 二種のガスを混合するとき, ガスが化学反応をしな いならば，各ガスのモル分率を $x_{1}, x_{2}$ とすれば,

$$
x_{1}+x_{2}=1
$$

が成り立つ。

混合ガスの密度はつぎの式で表わされる.

$$
\rho_{\text {mix }}=x_{1} \rho_{1}+x_{2} \rho_{2}
$$

つぎに, 混合ガスの粘度に関しては, Sutherland ${ }^{10)}$ 以来 多くの研究があるが, 本論文では Wilke $\mathrm{e}^{11)}$ の近似式を用い る.これは, 二種のガスを混合する場合, つぎのように表わ される。

$$
\mu_{\mathrm{W} \text { ilke }}=\frac{x_{1} \mu_{1}}{x_{1}+\phi_{12} x_{2}}+\frac{x_{2} \mu_{2}}{x_{2}+\phi_{21} x_{1}}
$$

ただし， $i ， j=1,2$ および 2,1 として

$$
\phi_{i j}=\frac{\left[1+\sqrt{\mu_{i} / \mu_{j}}\left(m_{j} / m_{i}\right)^{1 / 4}\right]^{2}}{\sqrt{8\left(1+m_{j} / m_{i}\right)}}
$$

である。

二種のガスの混合では $G, x_{1}, x_{2}, \rho_{V}, \mu$ が未知量であ る. (1)〜 (10) 式に強い簡略化の仮定を設けて, これらを求 めることは, 前報1)に扔いて試みた。本報告では, 簡略化を 排して，混合比推定精度の向上を図る。

\section{3. 式のパラメータの決定}

前章に記述した計算式に現われた諸量には, 幾何学的な量 のほかに, 実験的に求める必要がある流出係数, 理論的に定 まる膨張係数, Wilkeの式と実測值との相違など, 自明で ない量が含まれている. 本章では, これらの決定方法と, 測 定の結果を示す. 文献 1)ではベンチュリ管の係数 $k_{V}$ を近似 值 $k_{V} \approx(\pi / 4) d_{V}^{2}$ として計算を行なった。しかし，(2) 式に現 われた とと $C$ は 1 ではないし定数でもない.これらがどの ように変化するかを, まず調べ, 次いで混合ガスの粘度推定 式の検討を行なう。

\section{1 ベンチュリ管の膨張係数 $\varepsilon$}

膨張係数は $(4)$ 式に示したように， $\beta, \tau, \kappa$ の関数であ るからここらにより $\varepsilon$ の変化を数值的に示す.

まず，ベンチュリ管の入り口および出口の直径と接続管内 径は等しく $D_{V}=14.0 \mathrm{~mm}$, スロート直径は $d_{V}=6.15 \mathrm{~mm}$ である.よって， $d_{V} / D_{V}=\beta \approx 0.439$ である.

つぎに本研究で用いるガスの比熱比は, ガスの組み合わせ を総合すれば, 最小值が 1.3 (三原子分子 $\mathrm{CO}_{2}$ ), 最大值が 1.67 (単原子分子：アルゴン，ヘリウム) となる。混合気体の 
場合には, 混合比によって, 比熱比が変わる。この変化は質 量流量特性に影響を与える(前報1),2)ではこの一連の関係を無 視する単純化を行なった).

比熱比の変化は $\mathrm{Ar}-\mathrm{He}$ ではほとんどないが, $\mathrm{CO}_{2}-\mathrm{Ar}$ の 組み合わせでは変化が最大で, 1.67 から 1.30 までとなる. 使用条件での圧力比は 0.99 程度であるから, 膨張係数を 1 とみなす場合の誤差は, 最大で $0.6 \%$ に及ぶことがわかる.

\section{2 ベンチュリ管の流出係数 $C$}

つぎに流出係数は実験係数であって，レイノルズ数の関数 になることがわかっている7 ${ }^{729}$. 実験に使用するガスを使っ て, ベンチュリ管におけるレイノルズ数と流出係数の関係を あらかじめ求めておく必要がある。実験はつぎのように行 なった。

i ) 各ガスごとに, 湿式ガスメータ(株式会社シナガワ $\mathrm{W}-\mathrm{NK}$, 精度 $0.2 \%$ ) を用いて, 層流型流量計の校正を行な う.

ii ）ベンチュリ管上流はバッファタンクでガスの温度を安 定化し，サーボ弁により流量を定める。ベンチュリ管下流側 に校正済みの層流流量計を接続して, 流量を求め, 同時にべ ンチュリ管の上流圧力 $P_{V}$ と差圧 $\Delta P_{V}$ を測定する.

iii）（1），(2)式に測定した $\Delta P_{V} ， Q$ を代入して $C$ を求 める.このとき, $\rho_{V}=P_{V} /\left(R T_{V}\right)$ である.

こうして求めた流出係数 $C$ の結果を Fig. 2 亿示す. 当て はめ曲線の式は，(11)～(13) 式に示す. 式のパラメー夕を求 める計算は, 最小二乗法によった。残差平方和の平均平方根 (RMSE)を付記してある。

$$
\begin{aligned}
& R e=\frac{4 Q \rho}{\pi d_{V} \mu}=\frac{4 G}{\pi d_{V} \mu} \\
& 340<\operatorname{Re}<1700 \quad(\mathrm{RMSE}=0.00192) \\
& C=\frac{0.9347-124.6 / \mathrm{Re}}{1-45.42 / \operatorname{Re}}
\end{aligned}
$$

$2480<\operatorname{Re}<27600 \quad(\mathrm{RMSE}=0.003037)$

$$
C=\frac{1}{1+14.42 R e^{-0.6025}}
$$

流出係数はレイノルズ数が 2000 前後で特徵が変わってい るので，それぞれの範囲に当てはめ曲線を作成した. $R e=$ 1700〜2480の間はデータがないので，(12)式と (13)式の端 を近似的に結び，流出係数は定数 $C=0.885$ とした。

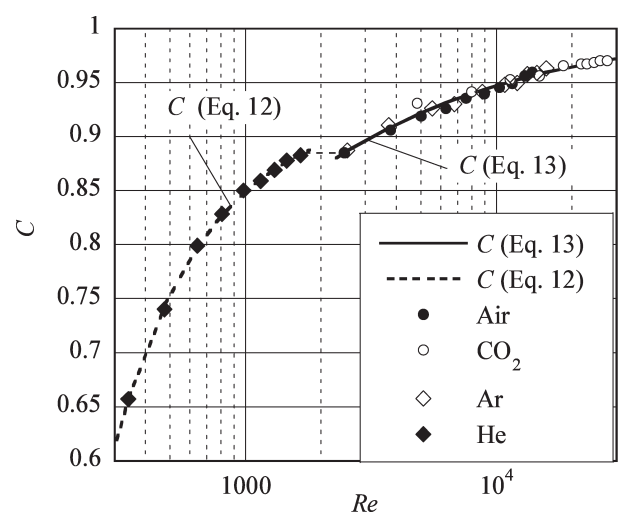

Fig. 2 Discharge coefficient of venturi meter
流出係数のデータが滑らかな 1 本の曲線で表わされないこ との理由は，この程度のデータでは断言できない.しかし， 一般的な推定は99, 流れが層流から乱流に移る遷移域が影響 をもたらしているとするものである.

\section{3 混合ガスの粘度}

混合ガスの粘度が（9)式，(10)式で概算できることは知ら れているが，この式は近似式である。それゆえ，近似に由来 する誤差を減らすことを考える，そのために，この区間にお いて, 混合ガスの粘度を測定し, 実験值により, 式の近似を 減少させる補間式を作成する。

この作業のために, 始めに実験により混合ガスの粘度を測 定する。まず混合比を定めた流体を流して, 層流型流量計に 発生する差圧から, 混合ガスの粘度を求める.この場合の実 験装置の概略は Fig. 3 に示す.

Fig. 3 において，ガス 1 はタンク (Gas source 1) に貯留し てあって，これに減圧弁 1 が接続され，その出力はバッファ タンク 1 に接続してある. バッファタンク 1 は圧力, 温度を ともに安定化させる $500 \mathrm{~mL}$ の等温化容器である. 等温化容 器から出るガス流量は, サーボ弁 SVによる流量設定を行な う.

質量流量 $G_{1}, G_{2}$ の測定を行なう FM1，FM2 は層流型流 量計で, これらの混合前ガスの体積流量と圧力損失の関係 を，湿式ガスメー夕を用いて校正をすませてある。なお， FM4 も同じ寸法仕様の層流型流量計である.またガスの温 度を監視するために，3つの層流型流量計すべてに熱電対温 度計が組み込んである。熱電対温度計の測定精度は $\pm 0.3 \mathrm{~K}$ である.

ガス 1 および 2 の流量は，層流型流量計 FM1 およびFM2 の出力を $\mathrm{A} / \mathrm{D}$ ボードを介して $\mathrm{PC}$ に取り込み，この值を サーボ弁にフィードバックして定值制御した。安定した測定 を行なうために，バッファタンク圧力は $0.5 \mathrm{MPa}$ とした。

この実験装置にはベンチュリ管も取り付けてあるが, 粘度 測定では，ベンチュリ管からの圧力信号は使用しない.

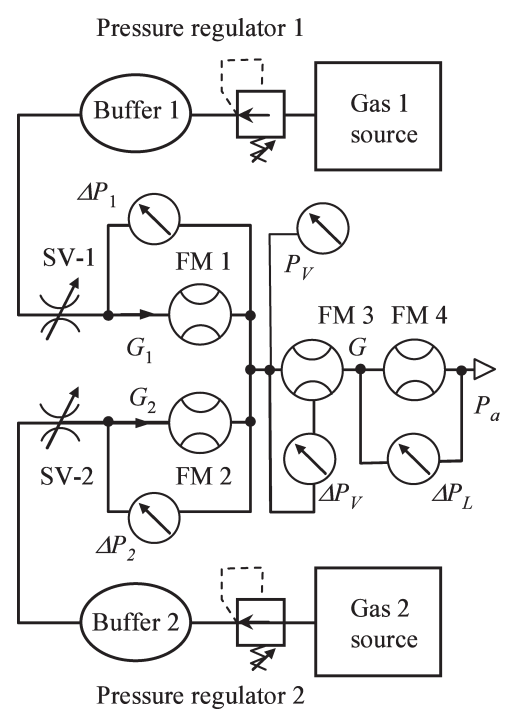

Fig. 3 Experimental setup for viscosity measurement 
FM4 で測定した体積流量と質量流量の関係は $Q=G / \rho_{a}$ で ある。これを用いると $(6)$ 式の関係は以下になる。

$$
\mu=\frac{2 K_{L}}{Q}\left(1+\frac{\Delta P_{L}}{2 P_{a}}\right) \Delta P_{L}
$$

ただし， $K_{L}$ は

$$
K_{L}=\frac{m d_{L}^{4} n_{L}}{256 l_{L}}
$$

であるが，内径 $d_{L}$ は必ずしも正確でないこともあるので, $K_{L}$ の值は，空気を用いた，湿式ガスメータによる校正によ り決定している。（14）式に，測定した差圧などを代入して求 めた粘度をWilkeの式と比較する.Wilkeの式は, 成分ガ スの粘度を既知として計算する内扱形の式である。すなわち $x_{1}=0 ， 1$ では，測定した粘度を用いるので，差は両端で 0 である。中間の $x_{1}$ に対する粘度の実験值とWilke の近似式 の值の関係を,

$$
\mu=\mu_{\mathrm{Wike}}+x_{1}\left(1-x_{1}\right)\left(a_{1}+a_{2} x_{1}+a_{3} x_{1}^{2}\right)
$$

と表わして， $a_{1} ， a_{2}, a_{3}$ を最小二乗法により求めることに より，Wilke 近似による誤差を減少させることができる. ただし， $\mathrm{CO}_{2}-\mathrm{Air}$ および $\mathrm{CO}_{2}-\mathrm{Ar}$ の場合は， $a_{3}=0$ とする。

このようにして，実験值から最小二乗法により求めた補正 式の係数は Table 1 のようになる. Table 1 には実験值と ( 9 )式で求めた值の差の平均二乗誤差(RMSEW) と, 実験 值と (16) 式で求めた值との差の平均二乗誤差 (RMSEC) も記 してある。また，分子量の大きいほうをガス 1 として，混合 比を横軸に，Wilkeの式と実験值の差を縦軸にとって，Fig. 4 に示す.

RMSEW は，Wilkeの式の近似誤差が含まれているが， RMSEC は，それを補間式により打ち消した後の誤差である から，これは実験誤差によると考えることができる。ここで は，RMSEC/RMSEW は，大きい場合で約 6\%となってい る. 粘度の值は, $1.4 \sim 2.3 \times 10^{-5} \mathrm{~Pa} . \mathrm{s}$ のオーダであるのに 対して RMSEW は $4 \times 10^{-7} \mathrm{~Pa} . \mathrm{s}$ のオーダであるから Wilke の式の近似誤差は $2 \%$ 程度であることがわかる.

また，本研究では空気を単一気体として，他の気体との混 合した場合を考察してきた。ところが，空気は周知のように 複数のガスの混合物である。そこで，Wilke ${ }^{11)}$ の式を用い て，空気を多成分 $\left(\mathrm{N}_{2}, \mathrm{O}_{2}, \mathrm{Ar}, \mathrm{CO}_{2}\right)$ として混合ガス粘度 を計算した值と空気を純物質のように扱って計算した混合ガ ス粘度(これには空気の実測值を使う) 比較する必要があ る、結果を比較すると，誤差は最大で $0.12 \%$ 程度であり, この差はWilkeの式で空気粘度を求めた值と実測值の差に よるものである。したがって，空気を純粋物質のように扱う ことにより発生する誤差は，空気粘度測定の観測値誤差より も小さい.その詳細な結果は付録に示す。

\section{4. 混合比と流量の推定}

本研究の課題は混合ガスを流して，2つの直列接続したべ ンチュリ管（FM3）と層流型流量計（FM4）に生じる圧力 降下を測定し，それらの值から，混合比と流量の同時推定を
Table 1 Property of interpolation

\begin{tabular}{cccc}
\hline Gas mixture & $\mathrm{CO}_{2}$-Air & $\mathrm{CO}_{2}-\mathrm{Ar}$ & $\mathrm{Ar}-\mathrm{He}$ \\
\hline$a_{1}$ & $1.36 \mathrm{E}-06$ & $2.80 \mathrm{E}-06$ & $-7.07 \mathrm{E}-06$ \\
$a_{2}$ & $-5.29 \mathrm{E}-07$ & $-2.69 \mathrm{E}-07$ & $2.55 \mathrm{E}-05$ \\
$a_{3}$ & 0 & 0 & $-2.01 \mathrm{E}-05$ \\
RMSE W & $1.83 \mathrm{E}-07$ & $4.49 \mathrm{E}-07$ & $2.21 \mathrm{E}-07$ \\
RMSE C & $5.02 \mathrm{E}-09$ & $2.84 \mathrm{E}-08$ & $5.29 \mathrm{E}-08$ \\
RMSEC/ & $2.75 \mathrm{E}-02$ & $6.33 \mathrm{E}-02$ & $2.39 \mathrm{E}-01$ \\
RMSEW & & &
\end{tabular}

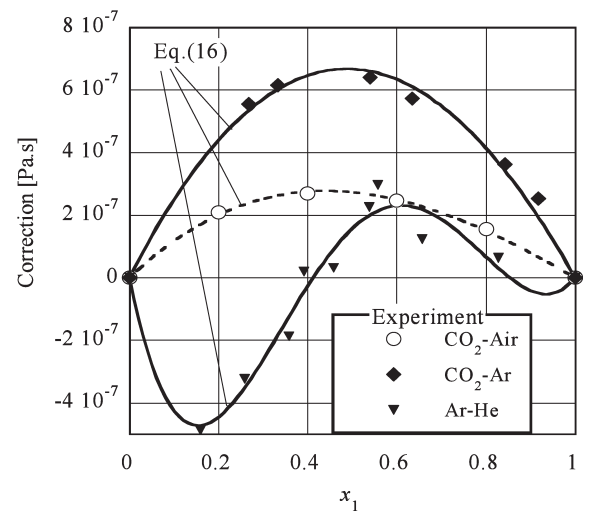

Fig. 4 Difference between Wilke's formula and experiment 行なうことである。これを行なうために，混合ガスを流し て, 流量計で観測される差圧, 絶対圧を測定する. しかる後 に, 混合比と流量の推定計算を行ない, 推定法の誤差評価を 行なう。したがって, 実験装置は 3 章に述べたものでよい が, ここではベンチュリ管における圧力, 差圧デー夕も使用 しなければならない.

\section{1 計算方法}

FM3，FM4 で観測する圧力と差圧から， $G$ と $x_{1}$ を計算 する.（3)式と（6)式で求める質量流量が等しくなる $x_{1}$ を 求めるのであるが， $0 \leqq 1 x_{1} \leqq 1$ であるから，二分法を適用し て， $G_{L}-G_{V}$ の大きさには注意を払わず，単純に 16 回繰り 返し計算を行なった。これで $x_{1}$ は $10^{-4}$ と以下まで正しく計 算できる。

$G_{V}$ の計算には, $C, R e$ を決定するための繰り返し計算 を行なう。C と $R$ の関係式は，(11)式と (1)，（2)，（3) 式から，

$$
R e-\frac{\pi d_{V}}{4 \mu_{V}} \frac{\varepsilon \sqrt{2 \Delta P_{V} \rho_{V}}}{\sqrt{1-\beta^{4}}} C=0
$$

である，この $C$ にReに応じて (12) 式，(13) 式のどれかを代 入して, 解を求める. 繰り返し計算では, 単純に繰り返し代 入法を用いた。これは方程式(12)，(13)式の性質がこの方法 に適合しているからで，繰り返しは数回で収束している.

\section{2 実験および推定計算の結果}

実験を行なったガスの組み合わせ，（1）二酸化炭素と空 気，（2）二酸化炭素とアルゴン，（3）アルゴンとへリウム， の三通りについて，以下に結果を示す。

実験を行なう混合ガスの予定流量を $0.5 \mathrm{~L} / \mathrm{s} ， 0.75 \mathrm{~L} / \mathrm{s}$, $1.0 \mathrm{~L} / \mathrm{s}$ の三通りとして，それぞれの流量につきガス 1 の割 合を，約 0.1 ずつ変えて実験を行なった。ガス 1 のモル分率 


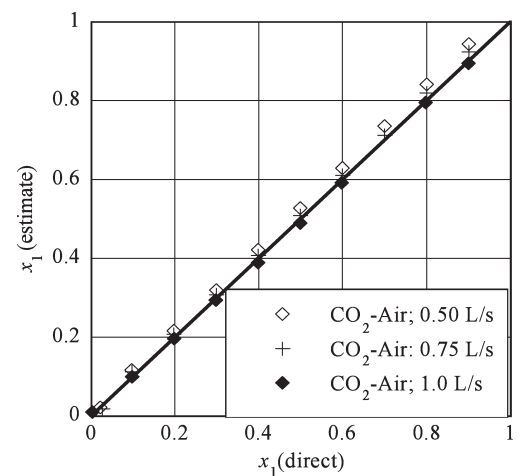

Fig. 5 Mole fraction of $\mathrm{CO}_{2}\left(x_{1}\right)$ and Air mixture

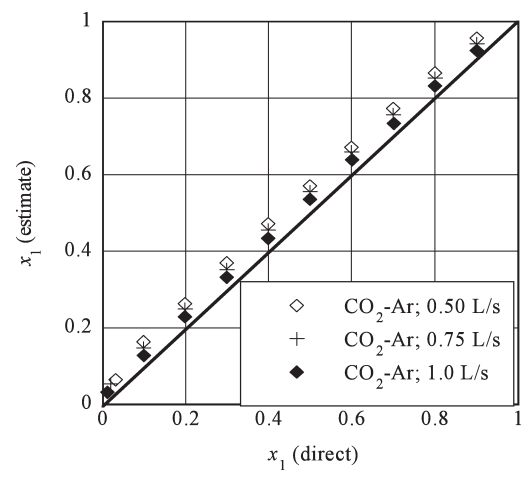

Fig. 6 Mole fraction of $\mathrm{CO}_{2}\left(x_{1}\right)$ and Argon mixture

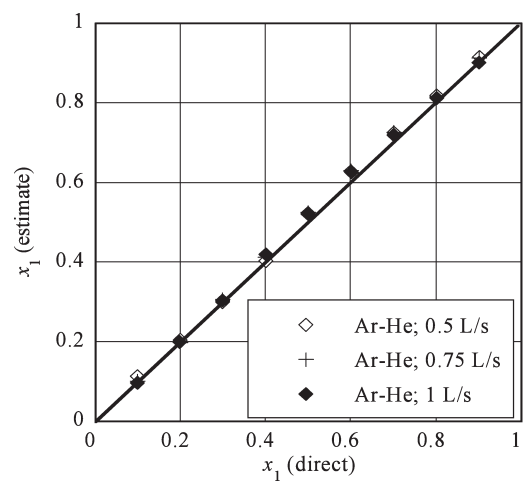

Fig. 7 Mole fraction of Argon $\left(x_{1}\right)$ and Helium mixture の測定值を横軸, ガス 1 のモル分率を縦軸にした線図を

Fig. 5, Fig. 6, Fig. 7 亿示す.

この実験における測定項目は，流量計 FM1，FM2 による 流量 (差圧から算出), ベンチュリ管 (FM3)に打りる差圧と 入り口圧力, 層流型流量計 (FM4)における差圧と入り口圧 力である。これらのほかに実験条件の監視用にガス 1,2 の 温度, 層流型流量計の温度を, 圧力などと同時に観測記録し てある.ガス 1,2 の流量, 温度が安定した定常值になって から，測定值記録をする。この装置の過渡現象は 1 秒程度で あるから, 起動後数秒で安定する. 混合比率と流量の計算に 用いる測定値は, 装置起動のおおむね 9 秒後の 1 秒間から $10 \mathrm{~ms}$ 跳びに測定記録した 100 の個のデータの平均值であ る.

(18) 式では $x_{1}$ (direct)を $x_{1, d}, x_{1}$ (estimate)を $x_{1, e s t}$ と書 く。これらはいずれも測定值から求めた量であり,これらの 量の差の平方平均を求める.すなわち
Table 2 Mixture estimate error

\begin{tabular}{cccc}
\hline Mixture & $\mathrm{CO}_{2}$-Air & $\mathrm{CO}_{2}-\mathrm{Ar}$ & $\mathrm{Ar}-\mathrm{He}$ \\
\hline$E_{x}$ & 0.018 & 0.051 & 0.018 \\
\hline
\end{tabular}

Table 3 Relative error of flow estimate

\begin{tabular}{cccc}
\hline Mixture & $\mathrm{CO}_{2}$-Air & $\mathrm{CO}_{2}$-Ar & $\mathrm{Ar}-\mathrm{He}$ \\
\hline $\operatorname{RMSE}\left(E_{G}\right)$ & 0.012 & 0.016 & 0.012 \\
\hline
\end{tabular}

$$
E_{x}=\sqrt{\frac{1}{N} \sum_{k=1}^{N}\left(x_{1, d}-x_{1, e s t}\right)_{k}^{2}}
$$

$(k$ : 測定点番号, $N$ : 測定点数 $)$

として, ガスの各組み合わせについて計算した結果を Table 2 に示す. Table 2 に示したように, $\mathrm{CO}_{2}-\mathrm{Ar}$ における濃度 推定の総合誤差は，5\%程度，他のガスの場合では $2 \%$ 未満 である。

つぎにこのシステムでは流量も同時に推定している.ベン チュリ管と層流型流量計システムから求める質量流量を, $G_{\text {est }}$ とし, FM1 と FM2 で検出した質量流量 $G_{1}, G_{2}$ を基準 とすれば，推定の相対誤差 $E_{G}$ は

$$
E_{G}=\frac{G_{e s t}}{G_{1}+G_{2}}-1
$$

である. $E_{G}$ も計測点ごとに異なった值を得るから，その RMSEを Table 3 に示す。その場合の RMSE は $2 \%$ 超え ていない.

\section{5. ま と め}

本研究では, ベンチュリ流量計と層流型流量計からなる混 合比率測定システムの特性を精査するために, 解析と実験を 行なった。まず，使用するベンチュリ管の流出係数を求め た。また，Wilkeの混合ガス粘度計算式に対する補正式を 作った。つぎに混合ガスが流れたときに, 直列接続した層流 型流量計とベンチュリ管に生じるそれぞれの圧力差から, 流 量と混合のモル分率を計算する手順を確立した。最後に，モ ル分率と流量を求める計算の有効性を実験により確かめた。

以上すべての知見を総合して, 著者らは, 広い範囲のガス の組み合わせに対して, 流量については $2 \%$ 以内, 混合のモ ル分率についても $5 \%$ 程度で推定でき, 屋外などの現場での 使用に利用できるものと考えている.

\section{参考 文 献}

1) S. Yamazaki, T. Funaki, K. Kawashima and T. Kagawa: A concentration measurement system for binary gas mixtures using two flowmeters, Measurement Science and Technology, 18, 2762/2768 (2007)

2) 荒川, 香川, 竹内, 六嘉, 染谷：管路内での異種ガス混合に関す る考察, 日本シミュレーション学会, 26-4,198/204 (2007)

3) 高橋, 佐々木:アドバンスセンサハンドブック, 培風館 (1994)

4）谷口, 村上, 村重, 小林, 田中：PLTZ 光シャッ夕を用いた赤外 線吸収方式 C2 ガスセンサの製作抢よび特性, 電子情報通信学 会論文誌 C-II, 81-8, 727/734 (1998)

5) J. C. Vyas, V. R. Katti, S. K. Gupta and J. V. Yakhmi : A non-invasive ultrasonic gas sensor for binary gas mixtures, Sensors and Actuators, B115, 28/32 (2006) 
6）舩木, 川嶋, 香川：高速応答性を有する気体用層流型流量計の 特性解析, 計測自動制御学会論文集, 40-10, 1008/1013（2004）

7） JIS Z 8762-4：2007, 円形管路の絞り機構による流量測定方法, 4 部：円すい形ベンチュリ管（2007）

8）工業計測技術大系編集委員会：工業計測技術大系-2，流量 (上), 日刊工業新聞社 (1964)

9) W. R. Miller: Flow Measurement Engineering Handbook, McGraw-Hill (1983)

10) W. Sutherland: The Viscosity of Mixed Gases, Philosophical Magazine, Fifth Series, 40, 421/431 (1895)

11) C. R. Wilke: A Viscosity Equation for Gas Mixtures, Journal of Chemical Physics, 18-4, 517/519 (1950)

《付

\section{録》}

\section{A. 空気が混合ガスであることの影響}

ここで扱った混合は，二種類のガスの混合であるが，その 中には空気も 1 つのガスとして扱っている。ところが，空気 は周知のように複数のガスの混合物である。これを純物質に 対するガス混合の式に使うということが正当であるかという 疑問がある。たとえば Wilke は $n$ 種のガスに対しても，二 種の場合と同じ式が成り立つとしている。すなわち， $n$ 種の ガスの混合では

$$
\mu_{\text {mix }}=\sum_{i=1}^{n} \frac{x_{i} \mu_{i}}{\sum_{j=1}^{n} \varphi_{i j} x_{j}}
$$

である。この式は重複回数の使用で，結果が同じにならな い.すなわち，三種を混合するとき，まず二種を混合し，そ れを純物質のように扱って三番目のガスと混合したときの粘 度と，上の式で $n=3$ として計算した結果とでは，式の上で は等しくならない.しかし，数值的に重要な差を生じるかど うかは，個々のガスごとに異なった結論になる，目下の問題 では，空気と他のガス，すなわち，アルゴンや二酸化炭素と の組み合わせではどうかという点を数值的に検討する必要が ある。

まず空気の成分は，詳細になると，測定地により，また文 献により差異があるけれども，概略值は共通で， $\mathrm{N}_{2}$ が $78 \%, \mathrm{O}_{2}$ が $21 \%, \mathrm{Ar}$ が $0.9 \%$ で残りは微量成分 $\left(\mathrm{CO}_{2}\right.$ は $0.033 \%$ )である. 成分比と粘度について，文献 10)，11）の 值を使って, $n=4\left(\mathrm{~N}_{2}, \mathrm{O}_{2}, \mathrm{Ar}, \mathrm{CO}_{2}\right)$ として, この式で空 気の粘度を計算すると（ただし数值計算では成分比を有効数 字 4 桁までとる。また，温度は $\left.20^{\circ} \mathrm{C}\right), \mu=1.816 \times 10^{5} \mathrm{~Pa} . \mathrm{s}$, となるが，空気粘度の測定值は $18.2 \times 10^{-5} \mathrm{~Pa} . \mathrm{s}$ 程度である からほほぼ致する。

つぎに他のガスを含めて $n=5$ として上記の式により計算 した值を $\mu_{\text {multi }}$ ，空気を純物質のように使って計算した混合 ガス粘度を $\mu_{\text {single }}$ と表わして(これには空気の実測值を使 う)，両者を比較したグラフを Fig. A. 1 に示す.

横軸は空気の分率で，空気 100\%のときに両者が一致しな いで，0.12\%程度異なるのは，Wilkeの式で空気粘度を求 めた值と実測值の差によるものである。この計算結果を参照 して，本文中では，空気を純物質であるかのように扱って， 粘度計算を行なった。図からわかるように，最大の差は中間

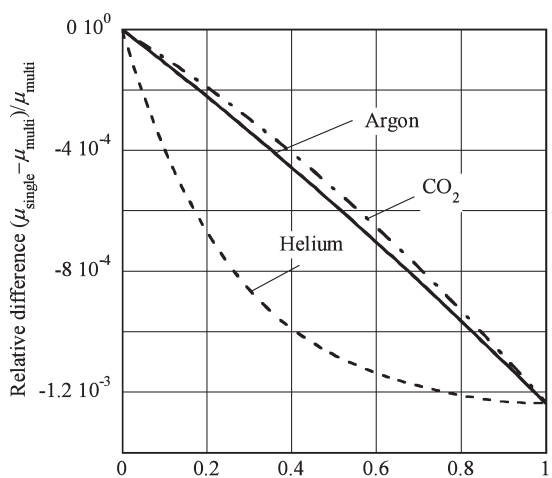

Air mole fraction

Fig. A. 1 Errors due to assuming air as a pure material の混合比においてではなく，空気そのもののときに生じるの である、したがって，空気を純粋物質として扱うことにより 発生する誤差は, 空気粘度測定の観測值誤差よりも小さい.

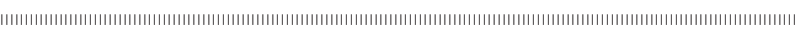

$$
\text { [著 者 紹 介] }
$$

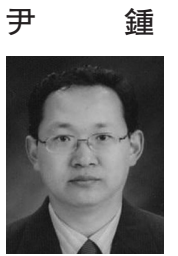

晧（正会員）

2005 年東京工業大学大学院精密機械システム 専攻博士課程修了。同年ボッシュ(株) 入社。2007 年東京工業大学精密工学研究所高機能化システム 助教, 現在に至る. 圧縮性流体の計測と制御の研 究に従事. 博士(工学). 日本フルードパワーシス テム学会, 日本シミュレーション学会の会員.

向 後晃

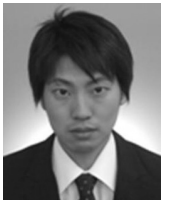

2008 年上智大学機械工学科学士課程卒業. 2009 年東京工業大学大学院総合理工学研究科义 カノマイクロ工学専攻修士課程修了. 現在, ソ ニー株式会社社員.

\section{川 嶋 健 嗣（正会員）}

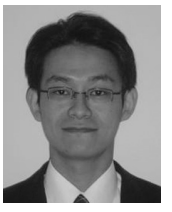

1992 年東京工業大学工学部制御工学科卒業. 97 年同大大学院理工学研究科制御工学専攻博士 後期課程修了. 同年東京都立工業高等専門学校機 械工学科助手, 2000 年東京工業大学精密工学研 究所助教授, 現在, 同大学准教授. 博士 (工学). 日本フルードパワーシステム学会, 日本機械学会 などの会員。

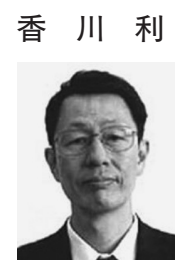

（正会員）

1974 年東京工業大学制御工学科卒業. 同年北 辰電機製作所入社, 76 年東京工業大学助手, 講 師, 助教授を経て, 現在, 精密工学研究所教授。 圧縮性流体システム，流体計測，生体計測に関す る研究に従事. 工学博士. 日本フルードパワーシ ステム学会, 日本機械学会, 日本シミュレーショ ン学会などの会員. 